\title{
Modelling and testing the electromagnetic near field shielding effectiveness achieved by woven fabrics with conductive yarns
}

DOI: $10.35530 / \mathrm{IT} .069 .03 .1508$

ION RĂZVAN RĂDULESCU

EMILIA VISILEANU

ION PĂTRU

LILIOARA SURDU

MARIAN COSTEA

VIORICA VOICU

\section{REZUMAT - ABSTRACT}

\section{Modelarea și testarea atenuării câmpului electromagnetic cvasistaționar obținută prin materiale țesute} cu fire conductive

Dezvoltarea accelarată a dispozitivelor electrice și a telecomunicației, necesită soluții adecvate pentru asigurarea compatibilității electromagnetice (CEM). Una dintre soluțiile principale oferite de CEM este ecranarea radiației electromagnetice (EM). Ecranele convenționale pentru radiație EM sunt construite din plăci metalice, însă utilizarea materialelor textile cu fire conductive inserate prezintă la rândul lor multiple avantaje: masă redusă, flexibilitate, rezistență mecanică și adaptabilitate la forme $3 D$.

Acest articol abordează ecranarea câmpului electromagnetic cvasistaționar și propune o relație analitică pe baza metodei separării variabilelor, care ține cont de parametrii geometrici și electrici ai materialului textil. S-a realizat un studiu de validare pentru relația analitică, prin determinarea atenuării electromagnetice într-o incintă, acoperită cu o husă din material textil cu fire conductive. Ansamblul experimental include atât dispozitivele electrice de măsurare, cât și un set de cinci materiale textile țesute cu fire conductive din inox și argint. Rezultatele experimentale pentru domeniul de frecvență al câmpului apropiat (1-20 MHz), prezintă valori bune în raport cu relația analitică.

Relația analitică simplificată permite calcularea distanței între firele conductive ale materialului țesut, în raport cu o atenuare EM specificată. Această relație sprijină procesul de proiectare al materialului textil, prin luarea în considerație a factorilor de cost și a atenuării EM specificate.

Cuvinte-cheie: ecranare, validare, distanță între firele conductive, bătătură, inox, argint

Modelling and testing the electromagnetic near field shielding effectiveness achieved by woven fabrics with conductive yarn

The current extensively development of electrical devices and telecommunication requires adequate solutions for ensuring electromagnetic compatibility (EMC). One of the main solutions provided by EMC is the shielding against electromagnetic (EM) radiation. Conventional screens for EM radiation are constructed from metallic plates, however, fabrics with conductive yarns may be used as well, with multiple advantages: lightweight, flexibility, mechanical resistance and $3 D$ shape ability.

The paper addresses the shielding of the electromagnetic near field, by proposing an analytic relation taking into account both geometrical and electrical parameters of the fabric, based on the circuit method. A validation study was performed, by measuring the shielding effectiveness of an enclosure with a cover from woven fabrics with conductive yarns. The experimental setup includes both the electrical measurement devices, as well as a set of five woven fabrics with conductive yarns from stainless steel and silver. The experimental results for the electromagnetic near field frequency range (1-20 MHz) present values in good relationship to the analytic relation.

The simplified analytic relation allows the computing of the distance between the conductive yarns of the woven fabric in relation to the targeted shielding effectiveness. This relation supports the design process of a fabric, with balance between its costs and its target shielding effectiveness.

Keywords: shielding, validation, distance between conductive yarns, weft, stainless steel, silver

\section{INTRODUCTION - the relevance of EM shielding textiles}

Fabrics with inserted conductive yarns may find adequate application in the shielding of electromagnetic waves [1-3]. Compared to the classical metallic shields, woven fabrics are flexible, lightweight and yet provide mechanical resistance. The applications of fabrics with conductive yarns range from curtains, tents or tarpaulins for protection of humans towards the outer radiation environment, to covers for limiting the inner radiation produced by enclosed electronic equipment [4-5]. Many applications are already on the market, however the modelling of the shielding effectiveness of woven fabrics is still an up-to-date question [6-7].

Modelling the shielding effectiveness of woven fabrics has numerous purposes and is an issue of current research [8-15]. One important purpose is related to 
the possibility of predicting the electrical properties of shielding based on the fabric's geometrical and electric parameters, before physically manufacturing the woven fabric. The modelling achieves valuable data for a cost-effective design. One basic question received from the textile industry's enterprises is related to the distance between the conductive weft yarns of a woven fabric, meant for achieving a certain shielding effectiveness. Moreover, the shielding of the electromagnetic near field is especially problematic to be achieved and requires special attention [4-5].

Thus, main aim of this paper is to propose and validate an analytical relation, comprising both geometrical and electrical parameters of the woven fabric, meant to answer the tasks above.

\section{THE ANALYTIC SHIELDING EFFECTIVENESS FOR THE ELECTROMAGNETIC NEAR FIELD}

The analytic shielding effectiveness relation was processed according to the circuit method, provided by Heinrich Kaden [16]. This analytic relation describes the shielding produced by conductive grid structures and thus, it is applicable for woven structures with conductive yarns. It represents a "mechanistic" mathematical model, as opposed to previous research operated with phenomenological mathematical models [17-18]. The analytic relation contains geometric and electric parameters and is valid for the electromagnetic near field. The figure 1 presents the principle of shielding for an enclosure build up with conductive grids (in our case woven fabrics), based on the Eddy currents induced by the incident variable electromagnetic field, which create an opposing field and consequently a shielding effect. The figure 1 includes the geometric parameters of the model.

The upper graph of figure 1 shows the two walls of the shielding enclosure, composed of fabric with conductive yarns in weft direction. It presents a front view of the enclosure. The distance between the walls is denoted with $2 x$, the distance between the conductive yarns in the weft structure with $a$, while the radius of the yarns is denoted with $r$. The lower graph of figure 1 presents an upper view of the shielding enclosure. According to this model, the yarns from the two walls of the enclosure are electrically connected at a certain specified distance, allowing the Eddy currents to flow withinclosed electrical circuits. The shielding factor $Q$ describes the ratio between the magnetic field strength of the inner field $\left(H_{y}\right)$ and the incident field $\left(H_{a}\right)$. It has according to [16] the following expression (1):

$$
\begin{aligned}
Q & \equiv \frac{H_{y}}{H_{a}}= \\
& =\frac{\rho_{i}+\mathrm{j}\left(\frac{r}{\delta}\right)^{2}\left[\lambda_{i}+\left(\frac{\pi r}{a}\right)^{2} W-\ln 2 \sinh \frac{\pi r}{a}\right]}{\rho_{i}+\mathrm{j}\left(\frac{r}{\delta}\right)^{2}\left[2 \pi \frac{x}{a}+\lambda_{i}-\ln 2 \sinh \frac{\pi r}{a}-\left(\frac{\pi r}{a}\right)^{2} W\right]}
\end{aligned}
$$

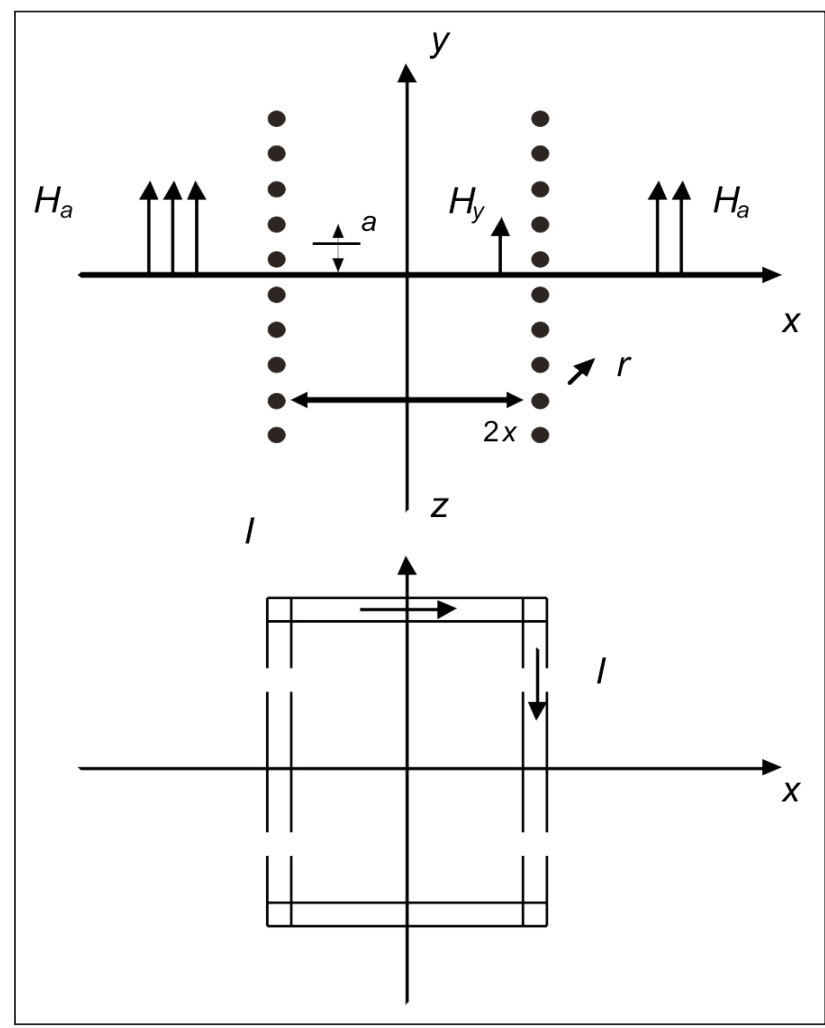

Fig. 1. The enclosure with electrically conductive grid

where the electric and geometric parameters are:

$r$ - yarn diameter;

a - distance between the conductive weft yarns;

$2 x$ - distance between the two walls of the enclosure;

$\delta$ - the skin depth (related to the frequency);

$\rho_{i}$ - resistance function;

$\lambda_{i}$ - induction function (expressed as ratio between $r$ and $\delta$ );

$W$ - reflexion factor.

The shielding effectiveness is expressed related to the shielding factor $Q$, either in Neper (2) or in Decibel (3), according to the following relations:

$$
\begin{aligned}
& \text { SENp }=\ln \left(\frac{1}{|Q|}\right)[\mathrm{Np}] \\
& \text { SEdB }=20 \log _{10}\left(\frac{1}{|\mathrm{Q}|}\right)[\mathrm{dB}]
\end{aligned}
$$

\section{THE FABRICS WITH CONDUCTIVE YARNS}

In order to achieve the desired shielding properties for the woven fabrics, conductive yarns from ferromagnetic (stainless steel - $\mathrm{Fe}$ ) and diamagnetic ( $\mathrm{Ag}$ ) raw materials were introduced into the weft system of the fabrics. A number of six electrically conductive yarns were analysed and used for the study. The first two yarns (F1001 and F1002) were twisted from three respectively two filaments, one of which from stainless steel. The third yarn (F2002) was a spun yarn with $80 \%$ cotton and $20 \%$ stainless steel content. The last three yarns (F1003, F1004, F1005) were from PA6.6 coated with Silver, having different yarn counts. Table 1 presents the physical-mechanical and electrical properties of these yarns. 
PHYSICAL-MECHANICAL AND ELECTRICAL PROPERTIES OF THE USED YARNS

\begin{tabular}{|l|c|c|c|c|c|c|}
\hline \multicolumn{1}{|c|}{ Property } & F1001 & F1002 & F2002 & F1003 & F1004 & F1005 \\
\hline Yarn count & 470 dtex & 220 dtex & $200,5 \times 2$ dtex & $301 \times 2$ dtex & $312 \times 4$ dtex & $148 \times 2$ dtex \\
\hline $\begin{array}{l}\text { Diameter yarn }(\boldsymbol{\mu m}) / \text { conductive } \\
\text { yarn }(\boldsymbol{\mu m})\end{array}$ & $287 / 60$ & $146 / 40$ & $273 / 54.6$ & 284 & 444 & 228 \\
\hline Twist $($ tors/m) & $488(\mathrm{~S})$ & $621.3(\mathrm{~S})$ & $593.6(\mathrm{~S})$ & $408(\mathrm{Z})$ & $480(\mathrm{Z})$ & $474.6(\mathrm{Z})$ \\
\hline Torsion $($ tors $/ \mathbf{m})$ & $828(\mathrm{Z})$ & $699.9(\mathrm{Z})$ & $827.6(\mathrm{Z})$ & $470(\mathrm{~S})$ & $502(\mathrm{~S})$ & $616.6(\mathrm{~S})$ \\
\hline Tenacity at breaking strength $(\mathbf{N} /$ tex) & 0.3657 & 0.1603 & 0.1365 & 0.4795 & 0.976 & 0.4564 \\
\hline Tensile strength $(\mathbf{N})$ & 17.19 & 3.528 & 5.46 & 28.77 & 58.5 & 13.69 \\
\hline Relative elongation $(\%)$ & 27.05 & 5.90 & 5.8 & 29.00 & 37.38 & 27.36 \\
\hline Linear electrical resistance $(\boldsymbol{\Omega} / \mathbf{m})$ & 6700 & 750 & 2200 & 76 & 30 & 220 \\
\hline Electrical resistivity $\left(\boldsymbol{\Omega}^{*} \mathbf{m}\right)$ & $4.3^{*} 10^{-4}$ & $1.25^{*} 10^{-5}$ & $1.29^{*} 10^{-4}$ & $4.81^{*} 10^{-5}$ & $4.65^{*} 10^{-5}$ & $9.01^{*} 10^{-5}$ \\
\hline Electrical conductivity $(\mathbf{S} / \mathbf{m})$ & $2.31^{*} 10^{3}$ & $7.97^{*} 10^{4}$ & $7.77^{*} 10^{3}$ & $2.08^{*} 10^{5}$ & $2.15^{*} 10^{5}$ & $1.11^{*} 10^{5}$ \\
\hline Relative magnetic permeability (1) & 7.36 & 9.93 & 7.36 & 1 & 1 & 1 \\
\hline
\end{tabular}

The diameter was determined with support of the optical microscope. The linear electrical resistance was determined with the multimeter and the electrical resistivity and conductivity was computed according to the formulae (4) and (5), whilethe relative magnetic permeability was computed by means of the formula (6) [19]:

Electrical resistivity

$$
\rho=R \frac{A}{l}
$$

Electrical conductivity

$$
\sigma=\frac{1}{\rho}
$$

Relative magnetic permeability

$$
\mu_{R}=M_{d e} M M_{d e} \mu_{M M}
$$

The following notations have been used:

$R$ is the linear electrical resistance for $1 \mathrm{~m}$;

$A$ - the surface of the yarn section;

$I$ - the length of $1 \mathrm{~m}$ of yarn;
$M_{d e}$ - the equivalent percentage of the material from total volume;

$M M_{d e}$ - the equivalent percentage of the magnetic material from total volume;

$\mu_{M M}$ - relative magnetic permeability of the magnetic material.

A relative magnetic permeability of stainless steel was set to $\mu_{M M}=40$, accordingly to [20], while $M_{d e}$ and $M M_{d e}$ were computed according to the yarn's twist/spun structure.

Based on these types of yarns, five variants of woven fabrics were manufactured. The woven fabrics were designed with the conductive yarns in the weft system at distances of $2 \mathrm{~mm}$ and $4 \mathrm{~mm}$. One woven fabric was designed with stainless steel conductive yarns in warp and weft system, with a grid of $4 \mathrm{~mm}$. Cotton yarns were used for the support structure of the fabrics. The following structural and physicalmechanical properties for the fabrics apply (table 2):

\begin{tabular}{|c|c|c|c|c|c|c|}
\hline & Standard & RAZ-1 & RAZ-2 & RAZ-3 & RAZ-4 & RAZ-5 \\
\hline Conductive yarn & - & F2002 & F1002 & F1005 & F1005 & F1003 \\
\hline $\begin{array}{l}\text { Pattern Conductive I } \\
\text { Cotton yarns }\end{array}$ & - & $\begin{array}{l}\text { Warp: } 2: 6 \\
\text { Weft: } 2: 6\end{array}$ & $\begin{array}{c}\text { Warp: - } \\
\text { Weft: } 6: 2\end{array}$ & $\begin{array}{l}\text { Warp: - } \\
\text { Weft: } 6: 1\end{array}$ & $\begin{array}{l}\text { Warp: - } \\
\text { Weft: } 3: 1\end{array}$ & $\begin{array}{l}\text { Warp: - } \\
\text { Weft: } 6: 1\end{array}$ \\
\hline Weave & - & plain & plain & plain & plain & plain \\
\hline Specific mass $\left[\mathrm{g} / \mathrm{m}^{2}\right]$ & EN 12127:1999 & 143 & 124 & 113.4 & 121.2 & 134 \\
\hline Density [no. yarns/ $10 \mathrm{~cm}$ ] - Warp & \multirow{2}{*}{ EN 1049:2:2000 } & 180 & 290 & 65 & 66 & 420 \\
\hline Density [no. yarns/ $10 \mathrm{~cm}$ ] - Weft & & 170 & 330 & 34 & 33 & 270 \\
\hline Material's thickness [mm] & EN ISO 5084/2001 & 0.55 & 0.72 & 0.33 & 0.33 & 0.49 \\
\hline Surface resistivity [W] & EN ISO 1149-1/2004 & $9.5^{*} 10^{2}$ & $2.72 * 10^{3}$ & $1.96 * 10^{14}$ & $8.83^{*} 10^{14}$ & 446 \\
\hline Volume resistivity $\left[\mathbf{W}^{*} \mathrm{~cm}\right]$ & EN ISO 1149-2/2004 & $3.7^{*} 10^{4}$ & $2.4^{*} 10^{4}$ & $2.18^{*} 10^{15}$ & $5.49 * 10^{15}$ & - \\
\hline
\end{tabular}

STRUCTURAL PARAMETERS AND PHYSICAL-MECHANICAL PROPERTIES OF THE WOVEN FABRICS 


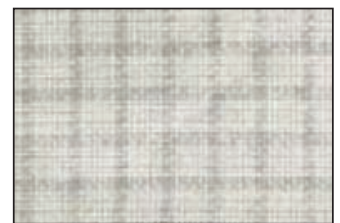

RAZ-1

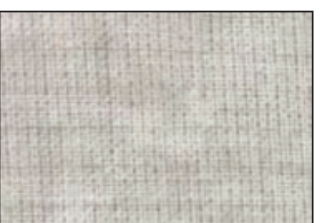

RAZ-2

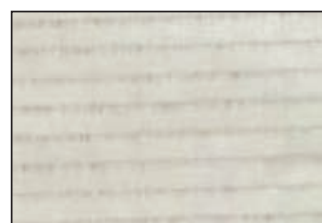

RAZ-3

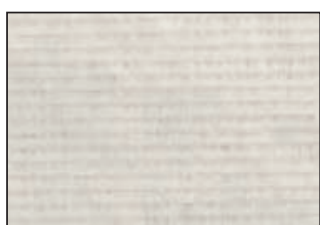

RAZ-4

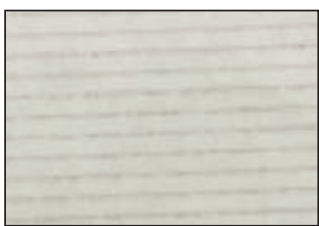

RAZ-5

Fig. 2. Pictures of the five woven fabrics performed

The surface resistivity is measured according to the standard EN ISO 1149-1/2004 in $\Omega$ s, due to the special geometry of the testing device, with two concentrically rings of specified dimension. The index $s$ indicates this exceptional measurement unit for the electrical resistivity. The investigation of yarns and fabrics was performed in the INCDTP accredited laboratories. Some pictures of the 5 woven fabrics are presented in figure 2 .

\section{EXPERIMENTAL RESULTS FOR THE SHIELDING EFFECTIVENESS}

In order to validate the analytic shielding effectiveness relation presented at section 2 , numerous physical tests on the fabrics were performed, within the EMC Laboratory of the Faculty of Power Engineering in University "Politehnica" Bucharest. An experimental setup was achieved, consisting of a shielding enclosure and the electric measurement system. The enclosure is constructed of a cube from wooden bars, each having a cross section of $2 \times 3 \mathrm{~cm}$ and a length of $100 \mathrm{~cm}$. Dry wood was chosen as material, for it has similar magnetic (permeability) and electric (permittivity) properties ofthe air, with no influence on the shielding measurements. The enclosure was completed by five covers out of the obtained textile materials for the cube with a side of $100 \mathrm{~cm}$.
The electric measurement system is composed of the following electronic devices:

- the signal generator;

- the power amplifier;

- the matching circuit for the magnetic emitting antenna;

- the magnetic field emitting antenna;

- the magnetic field receiving antenna (it's an active antenna);

- the spectrum analyser.

Thus, several measurements were performed, by placing the emission antenna inside the enclosure and the receiving antenna outside, both at a $30 \mathrm{~cm}$ distance from the wall of the enclosure. Figure 3 presents a block schema of the experimental setup, while figure 4 presents its elements.

The measurements were performed for two situations:

- without shielding enclosure (in order to measure the reference magnetic field $H_{a}$ );

- with shielding enclosure (in order to measure the inside magnetic field $H_{y}$ ).

The shielding measurements were performed at the frequency ranging between $1 \mathrm{MHz}$ to $20 \mathrm{MHz}$ for the electromagnetic near field. The upper limit of $20 \mathrm{MHz}$ was set accordingly to the standard IEEE 299.1, as the frequency range of [20 MHz, $300 \mathrm{MHz}$ is considered to initiate resonances within an enclosure

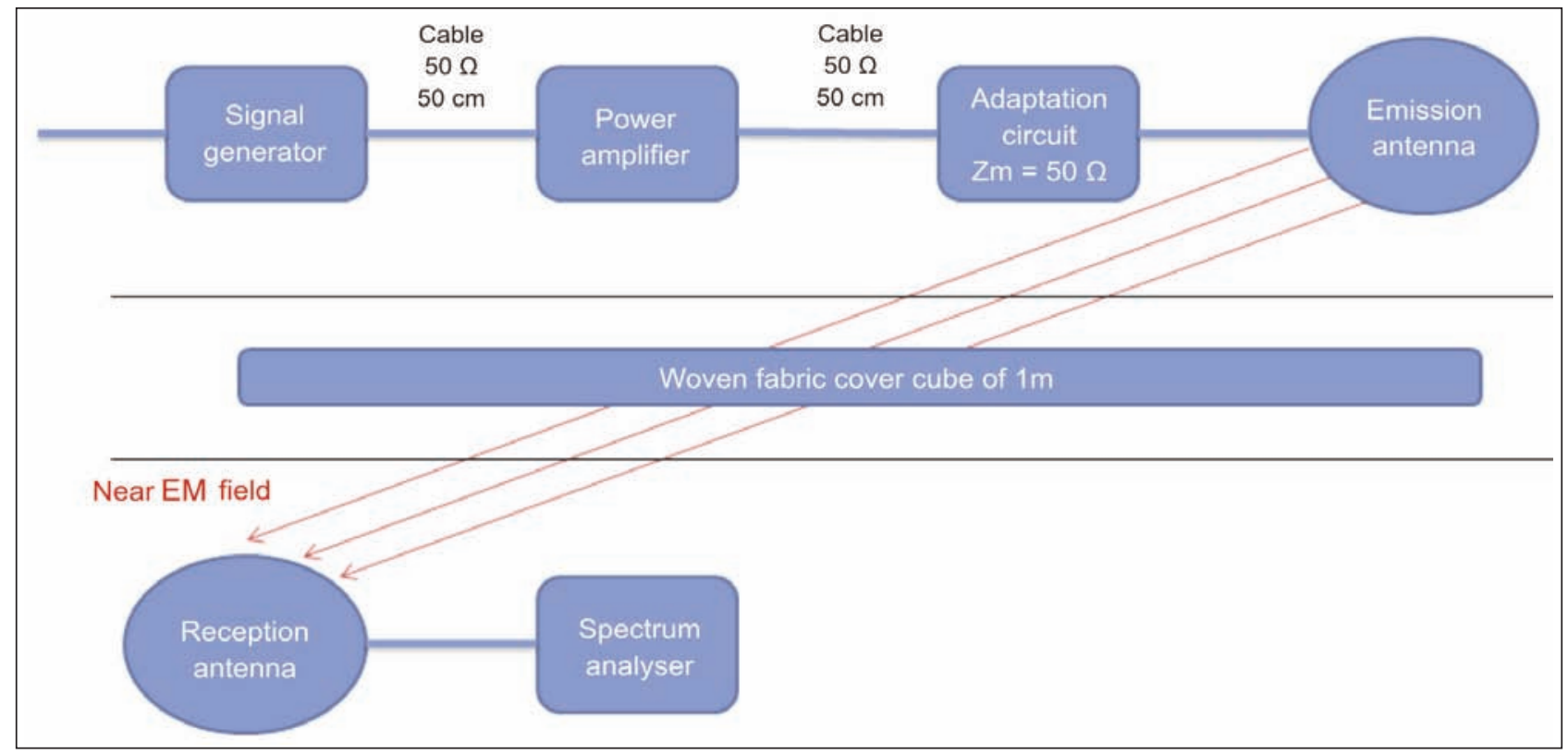

Fig. 3. Block diagram of the experimental setup 
EXPERIMENTAL RESULTS SHIELDING EFFECTIVENESS WOVEN FABRIC RAZ - 1 (STAINLESS STEEL)

\begin{tabular}{|c|c|c|c|c|}
\hline $\begin{array}{c}\mathbf{f} \\
{[\mathrm{MHz}]}\end{array}$ & $\begin{array}{c}\text { Output of power } \\
\text { generator } \\
{[\mathrm{dBm}]}\end{array}$ & $\begin{array}{c}\text { Reference measurement } \\
\text { without enclosure } \\
{[\mathrm{dBm}]}\end{array}$ & $\begin{array}{c}\text { Shielding measurement } \\
\text { with enclosure } \\
{[\mathrm{dBm}]}\end{array}$ & $\begin{array}{c}\text { Shielding effectiveness } \\
\text { (difference) } \\
{[\mathrm{dBm}]}\end{array}$ \\
\hline $\mathbf{5}$ & -20 & -7.2 & -6.4 & -0.8 \\
\hline $\mathbf{1 0}$ & -20 & -10 & -10 & 0 \\
\hline $\mathbf{1 2}$ & -20 & -10.4 & -10.8 & 0.4 \\
\hline $\mathbf{1 4}$ & -20 & -10 & -10.4 & 0.4 \\
\hline $\mathbf{1 6}$ & -20 & -9.6 & -10.4 & 0.8 \\
\hline $\mathbf{1 8}$ & -20 & -10.4 & -12 & 1.6 \\
\hline $\mathbf{2 0}$ & -20 & -6.8 & -16.8 & 10 \\
\hline
\end{tabular}

Table 4

\begin{tabular}{|c|c|c|c|c|}
\hline \multicolumn{5}{|c|}{ EXPERIMENTAL RESULTS SHIELDING EFFECTIVENESS WOVEN FABRIC RAZ - 5 (SILVER) } \\
\hline $\begin{array}{c}\mathbf{f} \\
{[\mathrm{MHz}]}\end{array}$ & $\begin{array}{c}\text { Output of power } \\
\text { generator } \\
{[\mathrm{dBm}]}\end{array}$ & $\begin{array}{c}\text { Reference measurement } \\
\text { without enclosure } \\
{[\mathrm{dBm}]}\end{array}$ & $\begin{array}{c}\text { Shielding measurement } \\
\text { with enclosure } \\
{[\mathrm{dBm}]}\end{array}$ & $\begin{array}{c}\text { Shielding effectiveness } \\
\text { (difference) } \\
\text { [dBm] }\end{array}$ \\
\hline $\mathbf{5}$ & -20 & -4.4 & -6 & 1.6 \\
\hline 10 & -20 & -8 & -7.6 & -0.4 \\
\hline 12 & -20 & -8.4 & -8 & -0.4 \\
\hline 14 & -20 & -7.6 & -7.2 & -0.4 \\
\hline 16 & -20 & -7.2 & -6.8 & -0.4 \\
\hline 18 & -20 & -9.2 & -8 & -1.2 \\
\hline $\mathbf{2 0}$ & -20 & -8 & -6.4 & -1.6 \\
\hline
\end{tabular}

having maximal dimension between $0,1 \mathrm{~m}$ and $2 \mathrm{~m}$. For frequencies exceeding $300 \mathrm{MHz}$, the electromagnetic near field condition is no longer satisfied. Repeatability conditions were ensured for all the measurements. Table 3 and table 4 present the shielding effectiveness results for the covers manufactured from the textile materials RAZ-1 (stainless steel yarns) and RAZ-5 (silver yarns).

The power of the electromagnetic signal is expressed in $\mathrm{dBm}$, while the shielding effectiveness is computed as difference between the reference measurement and the measurement with textile shielding enclosure. Table 4 shows that the measurements for the shielding effectiveness of the fabric with silver yarns has negative values, in the noise zone. This fact can be explained due to thediamagnetic behaviour of silver yarns and the better results of the ferromagnetic stainless steel yarns for the electromagnetic near field.

\section{SIMPLE FORM FOR THE ANALYTIC SHIELDING EFFECTIVENESS AND ITS VALIDATION}

Several mathematical simplification operations were performed on the analytic relation (1), by studying the premises of variation for the single parameters. The resulting relation (7) expresses the shielding factor depending both on the geometric parameters and the electric parameters of the enclosure. The electric parameters are included in the formula for the skin depth (8):

$$
\begin{gathered}
|Q|=\frac{1}{2 \pi} \frac{a}{x}\left(\frac{\delta}{r}\right)^{2} \\
\delta=\frac{1}{\sqrt{\pi f \sigma \mu}}
\end{gathered}
$$

with the following electric parameters of the conductive yarn's raw material (table 1):

$\sigma$ - electric conductivity [S/m];

$\mu-$ magnetic permeability $[\mathrm{H} / \mathrm{m}]$.

Figure 5 presents the shielding effectiveness related to the frequency on logarithmic scale. The following colour codes apply for the figure:

\begin{tabular}{|l|l|}
\hline Colour code & \multicolumn{1}{|c|}{ Description } \\
\hline & $\begin{array}{l}\text { The analytic shielding effectiveness } \\
\text { according to the literature (1) }\end{array}$ \\
\hline & $\begin{array}{l}\text { The simplified analytic shielding } \\
\text { effectiveness (5) }\end{array}$ \\
\hline & $\begin{array}{l}\text { The measured experimental data for the } \\
\text { shielding effectiveness for stainless steel }\end{array}$ \\
\hline
\end{tabular}

Thus, figure 5 shows in the first place, that the simplified analytic relation (7) models quite well the full analytic relation (1) from the literature, for the specified frequency range [16]. Secondly, the experimental values are smaller than the predicted ones and this fact can be explained by the fact that the analytic relation describes an ideal model and the electric conductivity for the yarns at the edges of the cube is only partially insured. However, the stainless steel yarns have 


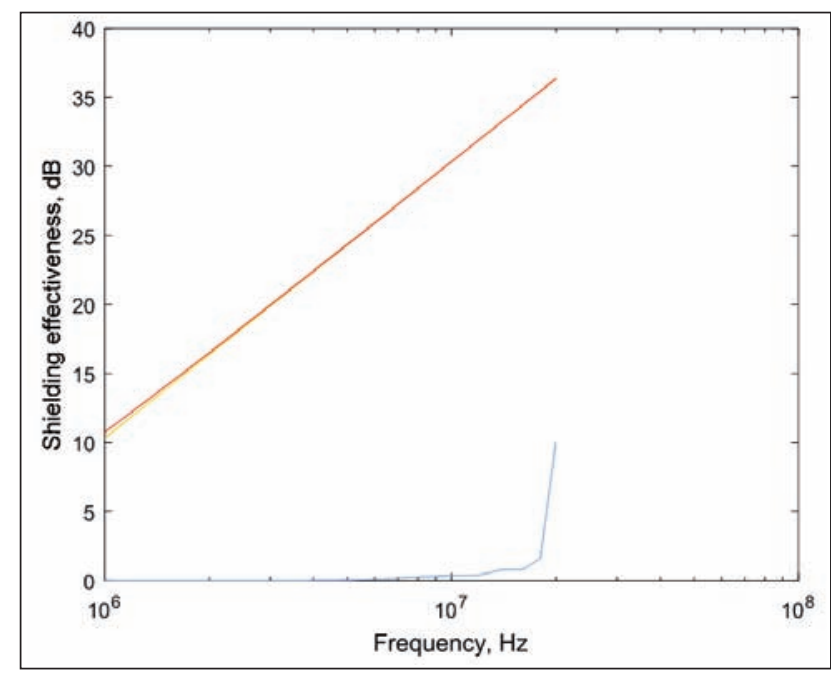

Fig. 5. Shielding effectiveness for analytic, simplified and measured values

a shielding effect on the magnetic near field, mainly due to their ferromagnetic nature.

\section{DISCUSSION}

One of the main questions identified at textile producers of woven fabrics with conductive yarns, was the necessary step of the grid - namely the distance between warp/weft yarns and its raw material, in order to achieve a specified shielding effectiveness. Figure 6 shows a parametric study for the shielding effectiveness (simplified relation) with various distances between conductive yarns. The following colour codes apply:

\begin{tabular}{|l|l|}
\hline Colour code & $a-$ distance between conductive yarns \\
\hline & $4 \mathrm{~mm}$ \\
\hline & $2 \mathrm{~mm}$ \\
\hline & $1 \mathrm{~mm}$ \\
\hline
\end{tabular}

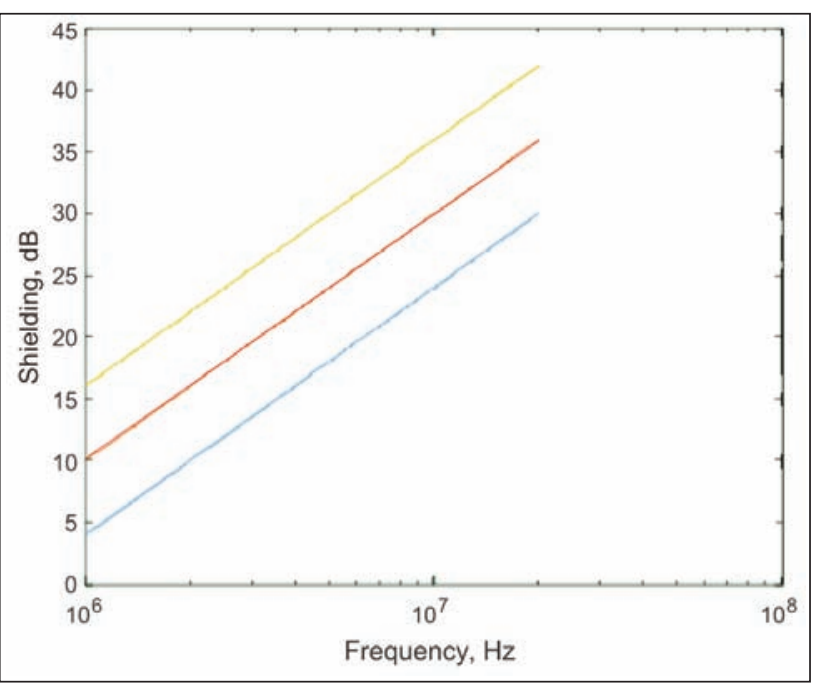

Fig. 6. Parametric study upon the distance between yarns

Figure 6 shows that a closer grid of conductive yarns has a better shielding effectiveness. This can be explained due to the higher electrical properties of the woven fabric. The simplified analytic relation for the shielding factor allows the computing of the distance between yarns $a$, in relation to the electric parameters of the yarn (electric conductivity $\sigma$ and magnetic permeability $\mu$, which are included in the formula of the skin depth (8)) and the geometric parameters of the enclosure (radius of the yarn $r$ and distance between shielding walls $2 x$ ). Hence, the distance between conductive yarns (parameter a) results from the relations (3) and (7):

$$
a=2 \pi x\left(\frac{r}{\delta}\right)^{2} 10^{-\frac{S E d B}{20}}
$$

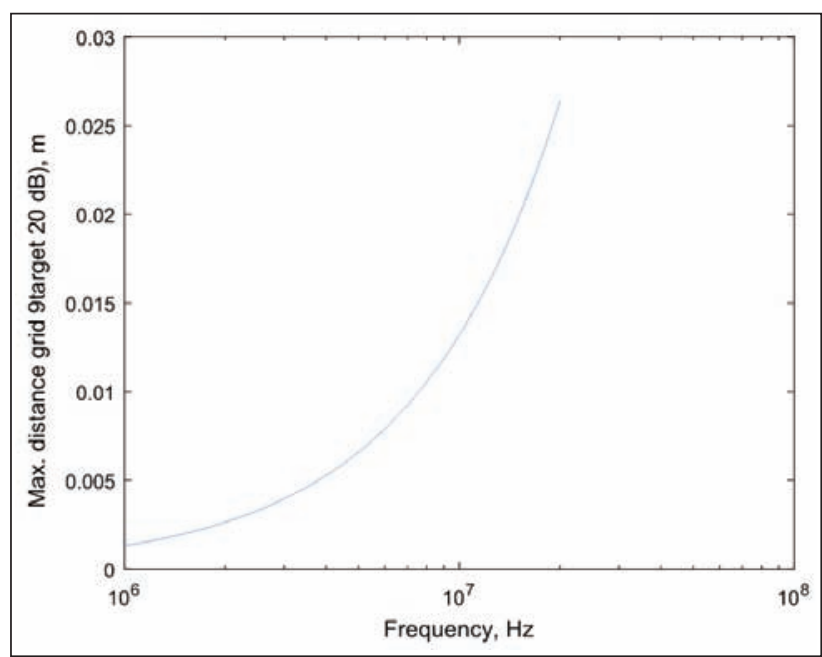

Fig. 7. Distance between conductive yarns for $20 \mathrm{~dB}$ shielding effectiveness and given parameters

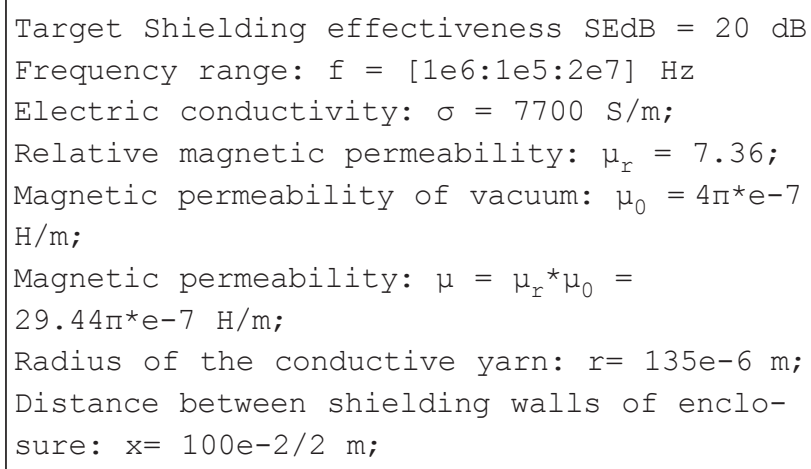

Figure 7 shows that the fabric requires a closer grid for smaller frequencies, at the same value for the shielding effectiveness. This is according to physics rules, for as known, the shielding of electromagnetic near field of low frequencies is very difficult to be achieved. On the other hand, the mechanical properties of a fabric with great density of conductive yarns could be a problem, due to their different mechanical tensile strength $(5.46 \mathrm{~N})$ and tenacity $(0.1365 \mathrm{~N} /$ tex $)$ when compared to the cotton yarns of the substrate tensile strength $(4.788 \mathrm{~N})$ and tenacity $(0.1197) \mathrm{N} /$ tex (table 1). This aspect can lead to difficulties when processing the woven fabrics. The cost of the conductive yarns represents another aspect, which requires optimization. 
Thus, the design of a conductive fabric for shielding of the electromagnetic near field has to achieve a balance between the specified shielding effectiveness, the distance between conductive yarns and the mechanical behaviour of the fabric. It is recommended to use stainless steel yarns for their ferromagnetic properties and their improved shielding of the magnetic field.

\section{CONCLUSIONS}

The paper proposes to study the shielding effectiveness of an enclosure for the near electromagnetic field. An analytic relation for the shielding effectiveness, taking into account both geometric and electric parameters of the conductive fabric, was simplified by the authors and a validation study was conducted. For the experimental part of validation, five woven fabrics with conductive yarns were manufactured, both ferromagnetic (based on stainless steel yarns) and diamagnetic (based on silver yarns). The proposed frequency range for testing is limited by the near electromagnetic field condition on one hand, and the resonance conditions specified by the standard IEEE 299.1, at $1 \mathrm{MHz}-20 \mathrm{MHz}$. The experimental results show smaller values for the shielding effectiveness as the analytic values, however these facts have two explanation: the electric continuity at the edges of the cube is only partially insured and the analytic relation represents an ideal model, very difficult to be reproduced with the used equipment. The experimental arrangement and the applied procedure are useful firstly to compare the features of different fabrics.
The simplified analytic relation givesa good approximation for the analytic relation fromthe literature for the specified frequency range and supportsthe computing of the distance between the conductive weft yarns in relation to the targeted shielding effectiveness. Thus, an important question addressed by the enterprises in the textile industry, that is the required distance of the conductive grid for woven fabrics and its raw material, may find an answer. A parametric study for the distance of the conductive weft yarns shows that the denser the conductive yarns, the better the shielding effectiveness of the electromagnetic near field. Calculations based on the proposed simplified relation are possible, in order to achieve an optimization between fabrics process ability, the costs and the targeted shielding effectiveness.

Future work envisages to refine and to extent for other frequencies the simplified analytic relation and also to add measurements, based on other arrangements and other set of antennas. The authors propose to achieve a correction of the analytic shielding effectiveness, meant to explainin a more accurate way the experimental values, as well as to provide additional experimental values for the electric properties of the conductive fabrics, based on other measurement methods.

\section{ACKNOWLEDGEMENTS}

The authors would like to thank to the general management of INCDTP for the support in the accomplishment of the studies and the work. This studies were performed with support of the Era-Net Manunet project TexEMFiRe, Grant agreement number 28/2018.

\section{BIBLIOGRAPHY}

[1] Bekaert - Bekinox: Internet resource: https://www.bekaert.com/en/products/basic-materials/textile/antistatic-fibers-for-textiles

[2] Shieldex - Statex: Internet resource: https://www.statex.de/fasern-und-garne/

[3] Swicofil: Internet resource: http://www.swicofil.com/products.html

[4] Schwab, A., Kuerner, W. Elektromagnetische Verträglichkeit, Springer, 2012.

[5] Costea, M. Metode și mijloace de asigurare a imunității electromagnetice, AGIR Publishing House 2006.

[6] Safe Solution: Internet resource: http://www.safesolution.ro/solutii-pentru-ecranare/

[7] Holland Shielding Systems BV: Internet resource: https://hollandshielding.ro/

[8] Negru, D. et al. Electrical conductivity of woven fabrics coated with carbon black particles, In: Fibres \& Textiles in Eastern Europe 2012, 20, 1(90) 53-56.

[9] Koprowska, J., et al. New type textiles with shielding properties. In: Fibres \& Textiles in Eastern Europe 2004; 12: 39-42.

[10] Aniolczyk, H., Koprowska, J. Application of electrically conductive textiles as electromagnetic shields in physiotherapy, In: Fibres \& Textiles in Eastern Europe October / December 2004, vol. 12, no. 4 (48).

[11] Rybicki, T., Brzenski, S. et al. Modelling protective properties of textile shielding grids against electromagnetic radiation, In: Fibers and Textiles in Eastern Europe 2013, 21, 1(97), pp. 78-92.

[12] Safarova, V. et al. A stufy of electrical conductivity of hybrid yarns containing metal fibers, In: University of Liberec, Journal of Materials Science and Engineering 2010, pp. 197-202. 
[13] Więckowski, T., Janukiewicz, J. Methods for Evaluating the Shielding Effectiveness of Textiles, In: Fibres and Textiles in Eastern Europe January / December 2006, vol. 14, no. 5 (59).

[14] Truhlar, M. et al. Electromagnetic shielding with the textile structures, TEXSCI International Conference 2010, Liberec, Czech Republic

[15] Zdenek Kubik et al., Shielding effectiveness measurement and simulation of small perforated shielding enclosures using FEM, 2015 IEEE 15th International Conference on Environment and Electrical Engineering (EEEIC), ISBN: 978-1-4799-7993-6.

[16] Kaden, H. Wirbelstroeme und Schirmung in der Nachrichtentechnik, Springer Verlag, 1959.

[17] Velten, K. Mathematical modelling and simulation, Rhein-Main University of Applied Sciences, WILEY-VCF Verlag, 2009, Germany.

[18] Radulescu, I.-R., Surdu, L. et al. Mathematical modelling of the shielding effectiveness for pes/stainless steel fabrics, In: Annals of the University of Oradea fascicle of textiles, leatherwork, vol. XVIII, nr. 1 2017, ISSN $1843-813 X$.

[19] White, D. A Handbook on Electromagnetic shielding materials and performance, Don White Consultants, 1980, USA.

[20] Internet resource: http://www.ugitech.com/uploads/ugitransfer/docs/GED_1591.pdf.

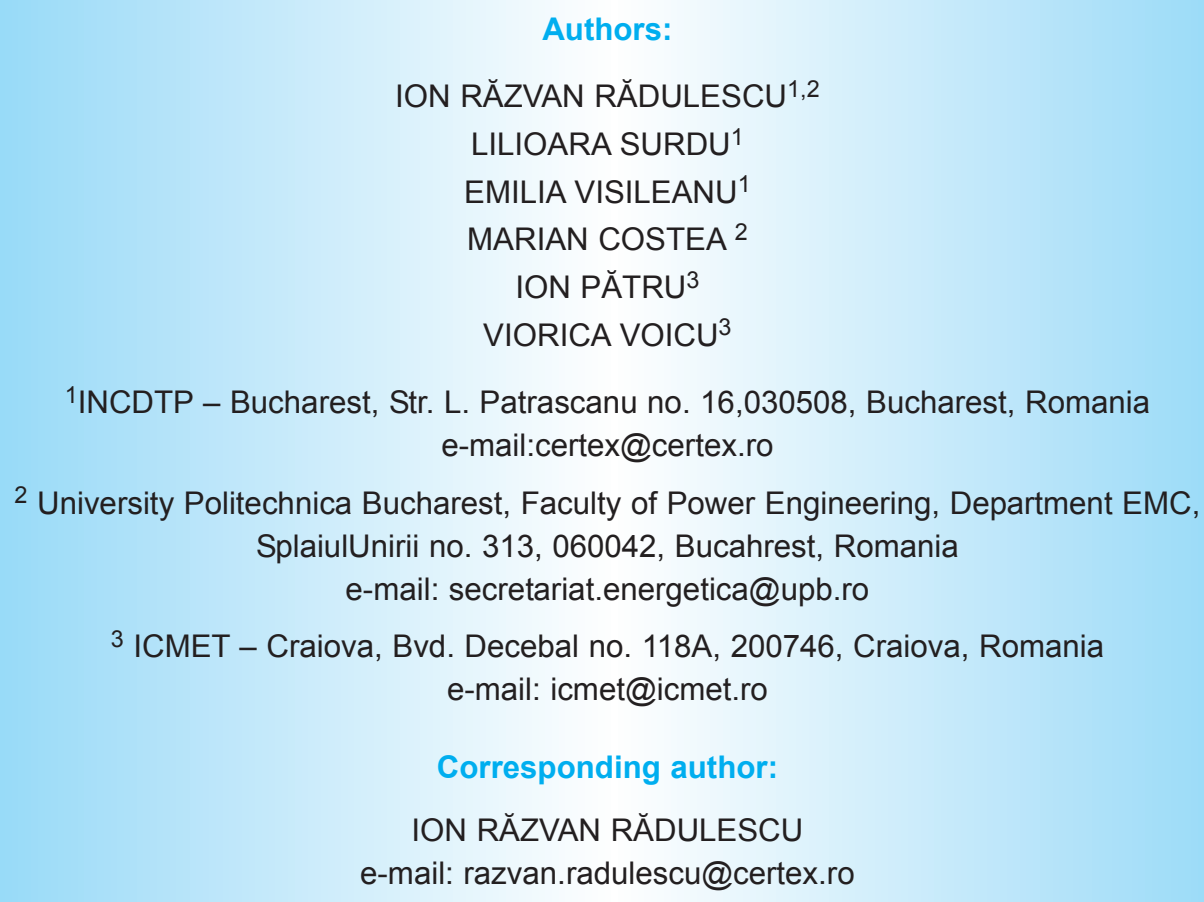

